\title{
Controlled Release Film Forming Systems in Drug Delivery: The Potential for Efficient Drug Delivery
}

\author{
Thao T. D. Tran ${ }^{1,2}$ and Phuong H. L. Tran ${ }^{3, *}$ \\ 1 Department for Management of Science and Technology Development, Ton Duc Thang University, \\ Ho Chi Minh City, Vietnam; trantruongdinhthao@tdt.edu.vn \\ 2 Faculty of Pharmacy, Ton Duc Thang University, Ho Chi Minh City, Vietnam \\ 3 School of Medicine, Deakin University, Geelong, Australia \\ * Correspondence: phuong.tran1@deakin.edu.au
}

Received: 31 March 2019; Accepted: 19 May 2019; Published: 20 June 2019

\begin{abstract}
Despite many available approaches for transdermal drug delivery, patient compliance and drug targeting at the desired concentration are still concerns for effective therapies. Precise and efficient film-forming systems provide great potential for controlling drug delivery through the skin with the combined advantages of films and hydrogels. The associated disadvantages of both systems (films and hydrogels) will be overcome in film-forming systems. Different strategies have been designed to control drug release through the skin, including changes to film-forming polymers, plasticizers, additives or even model drugs in formulations. In the current review, we aim to discuss the recent advances in film-forming systems to provide the principles and review the methods of these systems as applied to controlled drug release. Advances in the design of film-forming systems open a new generation of these systems.
\end{abstract}

Keywords: transdermal drug delivery; film-forming system; film; hydrogel; controlled drug release

\section{Introduction}

The development of controlled drug delivery systems has generated substantial interest in pharmaceutical science in recent years [1-3]. In particular, transdermal drug delivery has attracted researchers with multiple approaches because multiple dosing or insufficient drug delivery often results in low therapeutic effects [4-8]. Among these techniques, films (patches) and gels have been extensively designed for use in skin diseases or wound care in the past decades [9-17]. These dosage forms can also contain drugs for therapeutic applications.

Films or patches have the advantages of being a drug reservoir, having adhesive properties and providing precise performance at a targeted site on the skin, thereby prolonging drug release and improving therapeutic effects [18-21]. However, the fixed size and shape of these dosage forms are a limitation, especially for patients in some restrictive circumstances. In contrast to films, the hydrogel structure is flexible. However, the hydrogel structure has poor resistance to wearing and washing due to its hydrophilicity, although it has been reported in a sustained release form [22,23].

Fortunately, the ability of film-forming systems (FFSs) to transform non-solid dosage forms (such as gels and solutions) to films in situ has undergone substantial development to combine the advantages of both films and hydrogels. In fact, FFSs contain three main components- the drug, film-forming polymer and solvent(s) [24]. Upon contact with the target site (usually skin), the solvent will evaporate to form a film-loading drug [25].

The functionalization of polymers, drugs and other excipients in solid films could lead to controlled drug release. FFSs have shown therapeutic potential with various model drugs, especially in studying drug delivery through the skin. Here, we describe the basic concept of FFSs, including the generation 
of FFSs, and discuss the strategies used in developing a controlled drug release FFSs for effective therapies and the possible future development of this technology in the pharmaceutical industry.

\section{Principles of Film-Forming Systems}

FFSs can be a solution or dispersion in which drug and film-forming excipients are dissolved/dispersed in a volatile solvent(s) [6,24]. The liquid state of the FFS depends on the solubility of drug/excipients or dispersions of encapsulated drug microparticles/nanoparticles in solvents. Upon contact with the skin, the solvents will evaporate and form a film with excipients. Figure 1 illustrates the film formation of FFSs. With solution FFSs, the polymer can have tight contact via molecular interactions to build an even film or smooth film [26]. In contrast, the coalescence of particles after solvent evaporation from dispersion FFSs can result in rough surface films. In both cases, a plasticiser is usually added to the FFS to reduce the brittleness of polymer films [27-29].

(A)
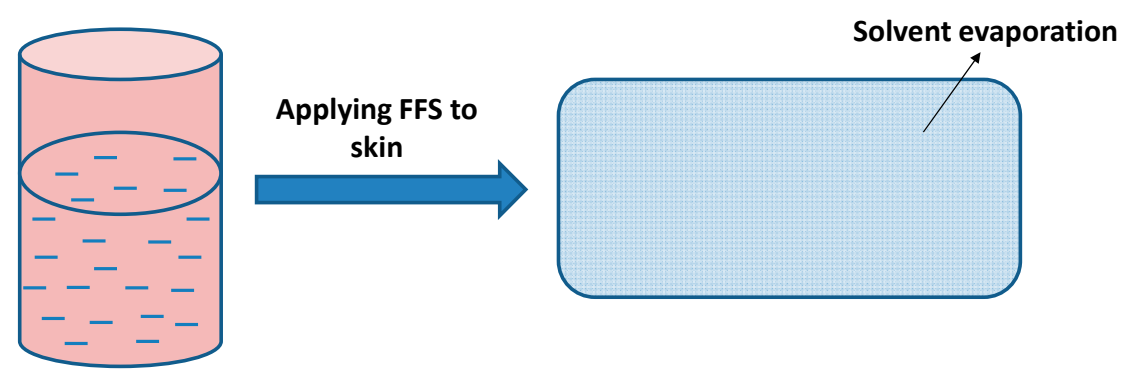

(B)
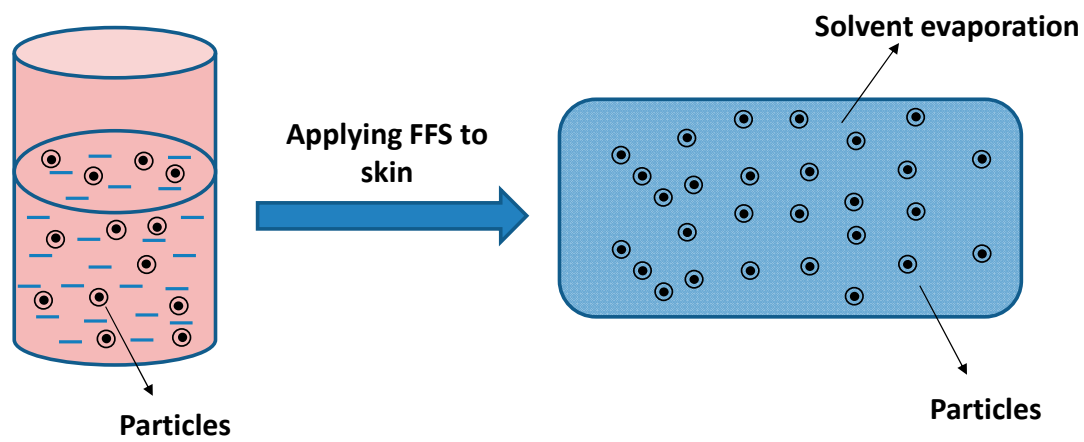

Figure 1. Illustration of film formation of film-forming systems (FFSs) containing solution (A) or dispersion of particles (B).

\section{The Generation of Film-Forming Systems}

\subsection{Film-Forming Solutions}

Since 1996, Amit Misra et al. has described film-forming solutions that have been known as the first generation of film-forming systems [30] (Figure 2). These authors noted that a film containing testosterone had efficient adherence to the skin by having sufficient tack. Consequently, high amounts of testosterone were diffused through the skin with biphasic of delivery the hormone, i.e., slow release rate after the initial burst release. In detail, the solution, which was applied to the skin surface, contains a polymer matrix of poly (vinyl alcohol) and poly (vinyl pyrrolidone) in isopropanol with a plasticizer (liquid paraffin) and a surfactant (Tween 20). These formulations were tested with in vitro skin permeation using Wistar rats. In later work, the authors successfully developed the experiment to evaluate the biphasic pharmacokinetics of testosterone in animal models (rat and monkey models) [31]. 


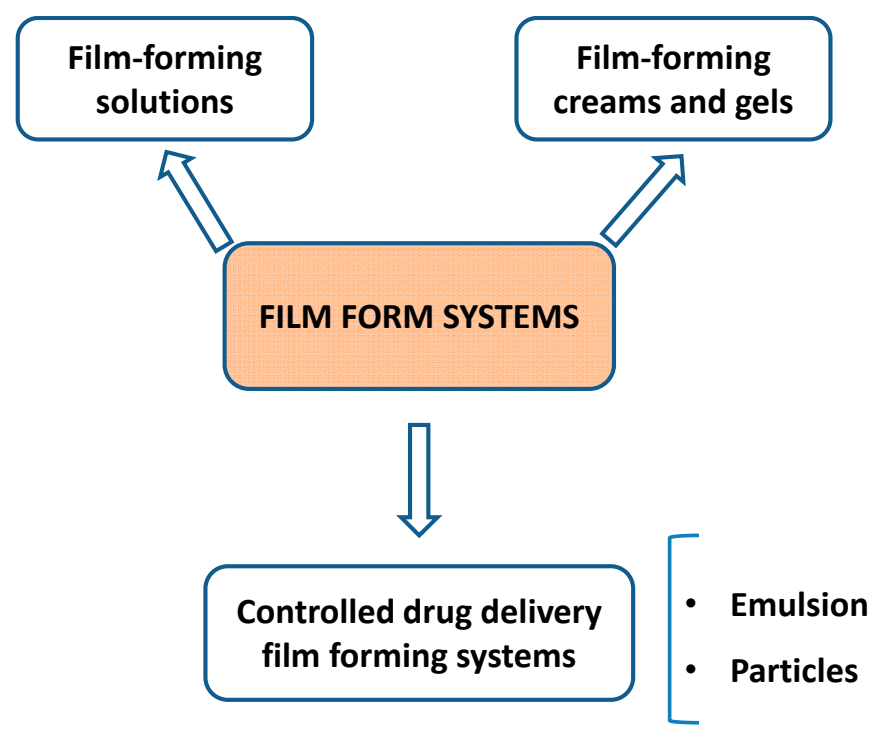

Figure 2. Illustrations of the generation of film-forming systems.

However, the above studies only discussed the efficiency of drug delivery in vitro and in vivo without focusing on the fabrication or evaluation of the film-forming systems. Therefore, Ines et al. first investigated polymer screening and characterization methods in 2007 to identify suitable formulations that were successfully tested in vitro (human epidermis) and in vivo (pigs) [32,33]. Important factors such as drying time, viscosity, cosmetic attractiveness, integrity, stickiness and mechanical properties were suggested [32]. In fact, quick drying time on the skin is necessary for patient compliance. Moreover, suitable viscosity ensures easy application of FFSs. The formulation also needs to be invisible for cosmetic attractiveness. The formulation should be non-sticky to avoid adhesion. Most importantly, FFSs must be retained for sustained drug release.

With the advantages of solutions, this type of film-forming system was recently developed and applied with spray formulations. For example, film-forming systems containing fluconazole and voriconazole were developed in 2009 and 2017, respectively [34,35]. The optimal formulation of fluconazole with Eudragit ${ }^{\circledR}$ RS 100 and ethyl cellulose was a flexible and mucoadhesive film when sprayed on human skin [34]. Similarly, the mixture of Eudragit ${ }^{\circledR}$ RLPO and ethyl cellulose showed that the spray formulation has the potential for applications in dermatological fungal infections due to the deep penetration of voriconazole into the skin [35].

Currently, most of the available market products are film-forming solutions, such as Axiron ${ }^{\circledR}$, Lamisil Once ${ }^{\circledR}$, Medspray ${ }^{\circledR}$. In 2008, Acrux (Australia) initiated a phase III clinical trial of Axiron ${ }^{\circledR}$ (the film-forming solution of testosterone) [36]. Axiron ${ }^{\circledR}$ was approved by the US Food and Drug Administration in 2010 and licenced to Eli Lilly globally [36,37]. The application dose (30 $\mathrm{mg}$ testosterone) of Axiron ${ }^{\circledR}$ comes in the form of a metered-dose pump (or twist) supplied with an applicator [38]. Another marketed film-forming solution is Lamisil Once ${ }^{\circledR}$ (GlaxoSmithKline Consumer Healthcare Australia Pty Ltd.) which contains terbinafine hydrochloride for the treatment of athlete's foot (tinea between the toes) with just one required application [39]. The ability of prolonged release in the skin of Lamisil Once ${ }^{\circledR}$ is the advantage of this product for a single administration $[24,40]$. Medspray ${ }^{\circledR}$ (MedPharm Ltd., UK) is the technology using "patch-in-a-can" concept which can also offer long residence of dosing in the skin or mucosal membrane after spraying film-forming solutions [41,42]. The "Liqui-Patch technology" technology (Epinamics GmbH, Germany) is also a sprayable film-forming solution [43]. The developed spray hood accompanied by the airless pump in this technology can maximize the film formation and minimize the cross-contamination [43]. 


\subsection{Film-Forming Creams and Gels}

Although film-forming solutions have proved to be effective formulations, researchers sought alternative dosage forms as a second generation of FFSs, such as creams or gels. The advantages of second-generation FFSs are high adhesiveness and easy application [6,44]. One noticeable report was the development of a cream containing the eutectic of lidocaine $(7 \%)$ and tetracaine $(7 \%)$ for application in cutaneous pulsed dye laser treatment [45]. This convenient system was then demonstrated to be effective for local anaesthesia in various studies and was approved by the Food and Drug Administration [46-49].

In 2003, Na-Mi et al. developed a film-forming soft hydrogel for transdermal delivery of testosterone using polyvinyl alcohol with a skin-permeation enhancer and an adhesive agent [50]. Polyisobutylene was used as an adhesive agent in the gel to reduce the contact angle and surface energy [50,51]. The gel was observed for $2-3$ min for forming a film after application, and the thin film was retained over one day.

In another intensive effort, a bioadhesive film was made to improve the quality of FFSs [52]. The authors designed an organic-inorganic hybrid gel with a comfortable film (thin and flexible) and high cosmetic attractiveness (transparent) [52]. This research also indicated that this bioadhesive film could facilitate drug diffusion by decreasing crystalline parts of the PVA structure [52].

Film-forming gels have shown potential in applications for wound healing. One advantage of film-forming gels is easy application to the wound site compared to wound dressings, especially uneven wounds, such as curved or shaped wounds [14,53]. For example, Dong et al. showed that FFSs containing sodium fusidate significantly improved infection wound healing in vivo [44]. In that study, a gel component including PVP/PVA/propylene glycol/ethanol/water had a film-forming time of approximately $4 \mathrm{~min}$ with appropriate adhesiveness, flexibility and elasticity [44]. The optimal product also demonstrated high drug release and improved wound infection healing in rats compared to commercial products [44]. It has also been shown that an FFS containing chitosan-polyvinyl alcohol at a nanoscale could enhance antibacterial and antibiofilm properties for facilitating wound healing [54].

The noticeable commercial product of film-forming creams and gels is Durapeel technology (Crescita Therapeutics ${ }^{\mathrm{TM}}$, Canada). This technology has demonstrated its capability of sustained drug release up to $12 \mathrm{~h}$ into the skin and its application with various active ingredients [55].

\subsection{Controlled Drug Delivery Film Forming Systems}

With the advantage of creating in situ delivery, FFSs are feasible and promising in controlled drug release for topical drugs due to their ability to prolong drug release with an on-skin drug reservoir. The intensive development of FFSs in recent decades probably led to advances in controlled drug release. The inclusion of particles in the system would open a new generation of FFSs.

It has been shown that semi-solid emulsions in film-forming emulsions containing nonivamide could spread onto larger skin areas and sustain dermal release for chronic pruritus therapy [56]. Although the sustained release was attributed to the ratio of water soluble and insoluble polymers, these features of emulsions in FFSs became a focus of studies on reducing the frequency of the application of topical drugs. Later, the same research group demonstrated similar results with capsaicinoids for treatment of chronic pruritus with a constant permeation rate maintained for $12 \mathrm{~h}$ for efficient drug concentration on the skin [57]. Those studies clearly demonstrated the advantage of this system compared to conventional emulsions. In the latest research, nonivamide was studied for loading on silica particles for incorporation into FFSs [58]. This study indicated that an FFS containing nonivamid loaded on silica particles not only sustained drug delivery but also had advantages of not using irritating emulsifiers in the FFS compared to two previous studies [56-58]. The other potential designs of FFS formulations for controlled drug release are discussed below. 


\section{Formulation Design of Controlled Drug Release Film-Forming Systems}

Generally, the formulations of FFSs contain a mixture of drug, excipients (polymers and plasticizers or additives such as penetration enhancers) and volatile solvents that can transform a liquid into a film on the skin surface after application. Therefore, several factors, such as the physicochemical properties of the drugs, the polymer and the plasticizer types and concentrations, the role of additives in formulations and the solvent evaporation will define the rate of drug release through the skin by modulation of drug saturation [33,59-68]. Therefore, these factors will be the focus of investigation for controlled drug release FFSs (Figure 3).

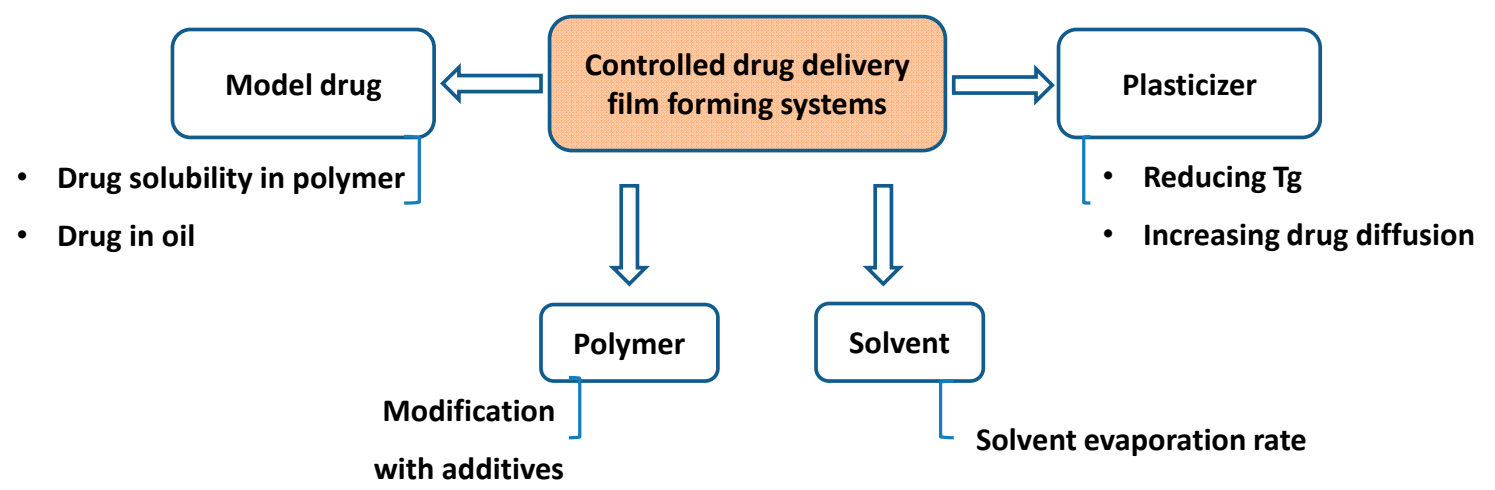

Figure 3. Illustration of factors in designing controlled drug delivery FFSs.

\subsection{Model Drugs}

The first step that should be considered in formulations is drug solubility in the film-forming polymers, which defines the drug saturation remaining on the skin surface. The ability of the drug to cross the skin greatly depends on the driving forces of drug saturation for triggering drug delivery. In recent research, drug solubility in the polymer has been suggested to be an important factor in controlling drugs crossing the skin [69]. In this study, methylphenidate was the free base and had a lower solubility in Eudragit ${ }^{\circledR}$ RS than in Eudgragit ${ }^{\circledR}$ E. Consequently, the higher degree of drug saturation resulted in higher drug release. Differential scanning calorimetry (DSC) has been proposed as a suitable drug solubility evaluation tool in the polymer for particular designs of FFSs for transdermal delivery [69]. Different weight fractions of drug and polymer were heated and measured by DSC. In fact, the melting enthalpy of drugs in different weight fractions of drug and polymer, which decreases during heating to the melting point, was used to measure drug solubility $[69,70]$. The maximum solubility of drugs was observed with the change in linearity of enthalpy because the drug could not be dissolved at this point [69].

To sustain drug release, Rouven et al. suggested dissolving model drugs in refined castor oil and then loading the drugs on the silica particles before incorporating them into film-forming polymer solution $[58,71]$ (Figure 4). The percentage of the drug in oil was $6 \%$, and the ratio between the drug solution and silica particles was 3:2, which was mixed with the plasticized Eudragit ${ }^{\circledR}$ RS 30D for creating the formulation containing $0.9 \%$ drug [71]. The results of ex vivo skin permeation, penetration and in vivo skin tolerability from these studies suggested prolonged drug release and no skin irritation for healthy volunteers [71]. 


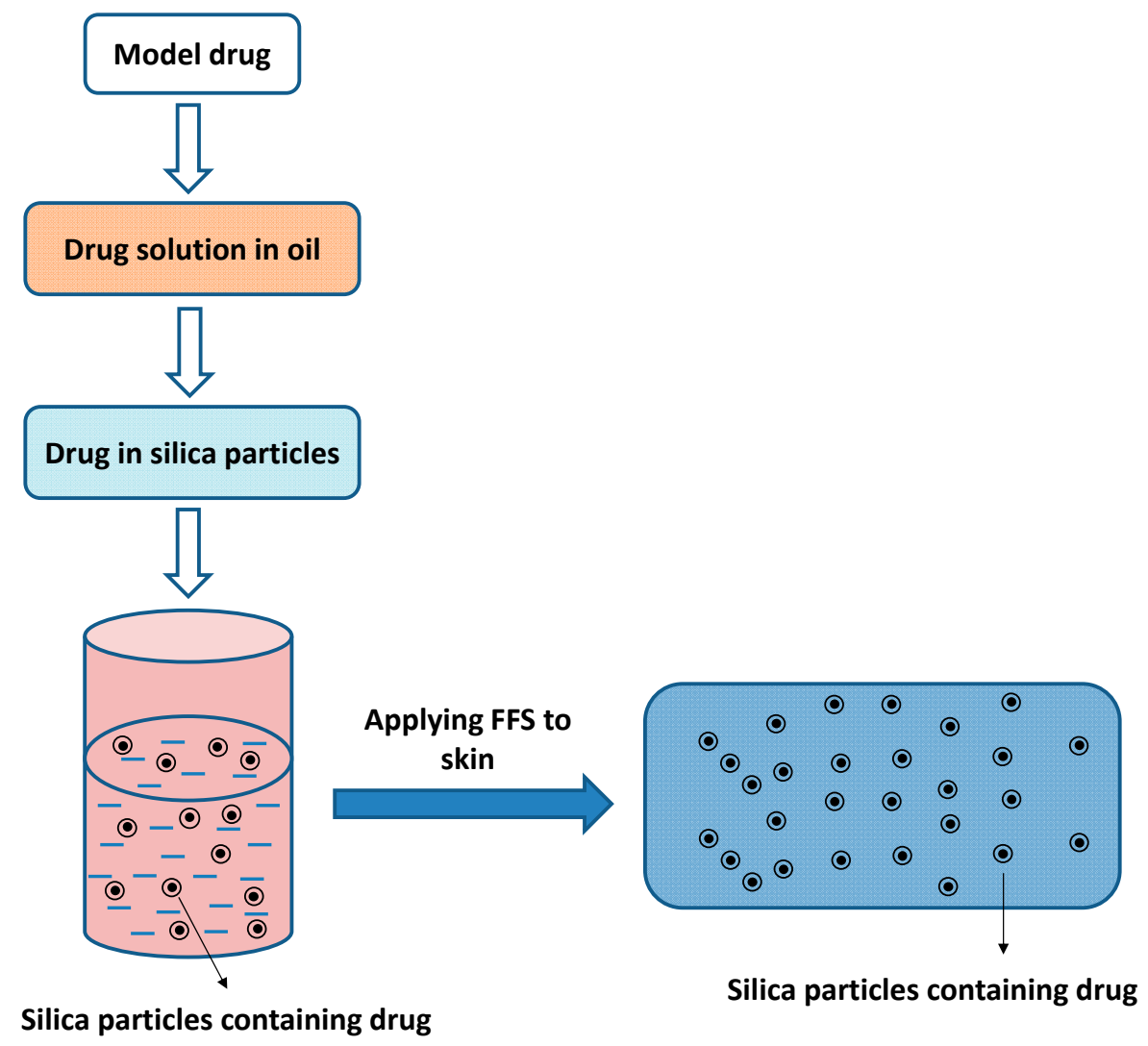

Figure 4. Illustration of a film-forming system containing particles for controlled drug release [58,71].

\subsection{Polymers}

Another strategy that has been used to control drug release is a modification of the film-forming polymer as a functional excipient. Oh et al. successfully grafted oleic acid on chitosan to increase drug skin permeation [72]. The inhibition of drug crystallinity formation and modulation of polymeric globules on the film caused by these grafts led to the improvement in drug permeability [72]. In another study, Hazel et al. used lipidic medium-chain triglycerides in a hydrophobic polymer (Eudragit ${ }^{\circledR}$ and Dermacryl ${ }^{\circledR}$ ) or hydrophilic polymer (hydroxypropyl cellulose) for an FFS to investigate betamethasone-17-valerate uptake into the skin [73]. The study indicated that the presence of medium-chain triglycerides in the hydrophobic polymer films facilitated the enhancement of betamethasone-17-valerate uptake into the skin compared to the hydrophilic polymer, which was explained by the hydrogen bond interaction between the model drug and the hydrophobic polymer [73]. The following is a brief summary of popular polymers used in FFSs.

Cellulose derivatives: Hydroxypropyl cellulose and ethyl cellulose are cellulose derivatives frequently selected for FFS preparations. While hydroxypropyl cellulose can be dissolved and swell to form a hydrogel in water, ethyl cellulose is water-insoluble [74-76]. However, ethyl cellulose can dissolve in an organic solvent to produce good film-forming properties and stability [77-79]. Typically, ethyl cellulose is used as a film-coating agent for sustained release in pharmaceutical formulations [80]. The mechanical properties of ethyl cellulose film depend on the molecular weight and viscosity [81]. Due to insolubility, ethyl cellulose is often preferred combined with hydroxypropyl cellulose for controlled drug release [82-85]. Specifically, the drug release and water permeability of the films depend on hydroxypropyl cellulose concentration in the films (the higher hydroxypropyl cellulose concentration is, the more increased drug release and permeability are) $[82,83,86]$. Moreover, hydroxypropyl cellulose is utilized with other polymers, such as Carbopol 934, to improve drug reservoirs in FFS formulations $[87,88]$. In addition to the role of gelling agent, Carbopol 934 and 
hydroxypropyl cellulose at an appropriate ratio could improve the drug release significantly (at the ratio $1: 5$ as reported) [87].

Polyvinyl pyrrolidone (PVP): The use of PVP facilitates a flexible selection of solvent for FFSs due to the solubility in both organic solvents and water of this polymer to produce good film-forming capacities [89-92]. Other advantages of PVP in FFSs are high hygroscopicity, good biocompatibility, and the ability to increase bioadhesive strength, which is probably explained by the formation of hydrogen bonds and Van der Walls' forces $[89,90]$. Therefore, PVP was investigated in various studies on wound dressing applications [44,93-98]. In some cases, the copolymer of polyvinylpyrrolidone-vinyl acetate is used instead of PVP [32]. The incorporation of vinyl acetate could result in reduced hygroscopicity [99].

Polyvinyl alcohol (PVA): Although PVA is well-known in vivo biocompatibility, the application of PVA in FFSs is concerning and restricted because of low hydrophilicity, rigid film generation and insufficient elasticity [100-102]. Therefore, PVA blends are recommended to improve the characteristics of PVA for use in FFSs, such as combining it with PVP [44]. The miscibility and good blending of PVP-PVA are attributed to the formation of hydrogen bonds between the $-\mathrm{C}=\mathrm{O}$ groups (in pyrrolidone rings of PVP) and -OH group (of PVA), resulting in good mechanical properties, good biocompatibility for various biomedical applications $[100,103,104]$. However, a large amount of PVP could lead to an open network structure and hence, inducing the formation of weak hydrogels $[100,105]$. Therefore, a small amount of PVP in a PVP-PVA blend has been recommended from $0.5-5 \%$ for stable hydrogels $[100,105]$. Moreover, a stable hydrogel was reported with the incorporation of low molecular weight PVA in the PVP-PVA blend as compared to the high molecular weight PVA [100].

Chitosan: Chitosan is a natural polysaccharide derived from chitin [106]. Due to its good biocompatibility and specific biological activities, chitosan has been exploited in various applications in drug delivery and regenerative medicine [107]. Specifically, the mucoadhesive nature and the presence of available functional groups in its chemical structure are important properties of chitosan to enable its utilizations in biomedical applications [108]. Similar to PVP, chitosan is usually applied for fabrication of a wound dressing due to the advantages of its biological properties (e.g., accelerating wound-healing), especially the blend of chitosan and PVP with antibacterial activity $[106,109,110]$. Moreover, the swelling and mucoadhesive properties have generated interest in FFSs, particularly film-forming gels $[32,59,110-112]$. For example, hydroxypropyl chitosan in controlled release FFS is a successful formulation that could demonstrate a higher permeation and penetration into the human nails as compared to a commercial product [113]. With regard to solubility, chitosan can be dissolved in an acidic solution, although it is insoluble in water and organic solvents [114,115].

Polymethacrylates: Although a broad range of polymers have been investigated for FFSs, polymethacrylates have been commonly studied for FFSs, such as Eudragit ${ }^{\circledR} \mathrm{RS}$ (ammonio methacrylate copolymer type B), Eudragit ${ }^{\circledR}$ NE 40D (poly(ethyl acrylate-co-methyl methacrylate) 2:1), Eudragit ${ }^{\circledR}$ E 100 (poly(butyl methacrylate, (2-dimethylaminoethyl)methacrylate, methyl methacrylate) 1:2:1), Eudragit ${ }^{\circledR}$ RL PO (Ammonio methacrylate copolymer), and Eudragit ${ }^{\circledR}$ S 100 (poly(methacrylic acid, methyl methacrylate) 1:2) $[33,56,59,98,116,117]$. Polymethacrylates have excellent properties for FFSs with high flexibility, skin compatibility and controlled drug release [118].

\subsection{Plasticizers}

In addition to polymers, plasticizers also contribute to drug delivery through the skin by not only reducing the glass transition temperature $(\mathrm{Tg})$ of the formed polymeric films but also increasing drug diffusion [59]. For example, Eudragit ${ }^{\circledR} \mathrm{RS}$, with high Tg (approximately $65^{\circ} \mathrm{C}$ ), should be incorporated with a plasticizer for use on the skin surface (temperature approximately $\left.32{ }^{\circ} \mathrm{C}\right)[59,119,120]$. Plasticizers can increase the free volume and chain mobility of polymers, thereby improving drug release $[59,121,122]$. 


\subsection{Solvents}

Although solid excipients play key roles in FFS formulations, the solvent evaporation rate is also involved in drug permeation through the skin. Specifically, a study on Eudragit ${ }^{\circledR}$ RL as a polymer using different model drugs (flurbiprofen, ibuprofen and ketoprofen) indicated that the initial burst drug release could be archived if the evaporation rate of the mixture of acetone and isopropyl alcohol in the FFS was slow [123].

With the development of hydrogel nanoparticles with many applications and the benefits of nanoparticles, there is also a great opportunity for the inclusion of other types of nanoparticle research in FFSs [124-136]. For example, a future study will provide a detailed understanding of how nanosized drugs can be incorporated and stabilized in FFSs and be delivered effectively to targeted sites. New insight into system mechanisms, such as the film transformation phenomenon and the ability of FFSs to deliver different drug nanoparticles, will be discovered. Therefore, knowledge of encapsulation and release behaviours of nanoparticles in FFSs will be improved to develop advanced materials for effective topical products.

\section{Evaluation of the Physico-Chemical Properties of Controlled Drug Release Film-Forming Systems}

\subsection{Physicochemical Characterizations}

The physical characterization of FFSs is associated with their hardness, adhesiveness, drying time, flexibility, and elasticity to maintain the contact between the film and skin as well as the resistance from the physical movement of skin $[44,137]$. The hardness and adhesiveness can be measured by a texture analyser [44,137]. While hardness is defined as the maximum force during a movement of a disc into a gel, adhesiveness is the ability of an FFS to adhere on a disc which is determined by the force of a disc in the upward movement [137]. To evaluate the in vitro film-forming drying time, a small amount of FFS is put into an acrylic plate (or Petri dish, microscopic slide) and observed by naked eyes $[44,59,138,139]$. The observations of the degree of uniformity, cosmetic appearance (such as transparency), and peelability are also evaluated in some circumstances [6,59]. The stickiness of an outer dried FFS can be determined by applying cotton wool with low pressure to evaluate the ability of adherence to fibres [32]. Furthermore, the mechanical properties of a dried FFS such as flexibility, elasticity are investigated through the determination of tensile strength and elongation at break using texture analysis [44]. The maximum weight which is loaded at the time of rupture of dried FFS is defined as the tensile strength [32,44]. Besides, the comparison of initial dried FFS length with FFS length at break determines the elongation at break (\%) [32,44]. Microscopies such as atomic force microscopy and Raman microspectroscopy also provide the mechanical and topographical information of a dried FFS at the nanoscale [117]. Other common instrumental analyses are recommended for various purposes of a study. For instance, to detect drug crystallinity in a dried FFS, powder X-ray diffraction and differential scanning calorimetry are critical analyses; or to identify the molecular interactions between the drug and other excipients (or between excipients), Fourier-transformed infrared spectroscopy and nuclear magnetic resonance should be included [27,76,140-142].

\subsection{Drug Release and Drug Penetration Evaluation}

For an evaluation of drug release, Franz diffusion cell or dialysis instrument is selected for in vitro study $[44,56]$. However, the dialysis tube has a disadvantage of dissolving the dried FFS during its contact with the dissolution medium. In contrast, while the donor compartment of the Franz diffusion cell is the place to attach an FFS to a diffusion membrane (or excised skin for ex vivo study) and expose the dried FFS to the atmosphere, the receiver compartment contains the diffusion medium allowing drug permeation from a dried film [56]. Controlled drug release FFSs for a prolonged time can affect the passive diffusion of water through the skin, which may change the percutaneous drug absorption (e.g., change blood flow, skin temperature, etc.) [32,143-145]. Therefore, the determination 
of water vapour permeability of a dried film by the VapoMeter is an important factor in controlled drug release FFSs [32,73]. Additionally, to further investigate uptake of drug in the skin, ex vivo skin penetration should be performed. Typically, an FFS is applied to the intact skin surface of porcine ears evenly and maintained at $32{ }^{\circ} \mathrm{C}$ with $\mathrm{pH} 7.4$ as the diffusion medium in Franz diffusion cells $[73,146-148]$. At a predetermined time post-application, the residual FFS is cleaned from the skin surface $[73,149]$. Subsequently, the stratum corneum, epidermis and dermis are removed by taping and stripping to extract the amount of drug penetration using an organic solvent $[73,148,150]$. The amount of drug in filtered extracts is determined by an appropriate method (e.g., high performance liquid chromatography) [148].

\section{Conclusions}

Several studies of FFSs have demonstrated potential applications in therapeutics. The efforts to design controlled drug release FFSs are expected to provide an efficient system for the modulation of drug release, not only for transdermal drug delivery but also for other types of drug delivery. The generation and inclusion of particles in FFSs can improve drug delivery at the targeted site. This strategy and many other systems (e.g., nanoparticles) will open the possibility of optimizing the manufacturing process for FFSs in the future. Moreover, other strategies including the optimization and modification of polymers, plasticizers, and drugs are also key factors in the research and development of controlled drug release FFSs.

Author Contributions: Writing-original draft preparation, T.T.D.T.; writing-review and editing, P.H.L.T.

Funding: Phuong Ha Lien Tran is the recipient of Australian Research Council's Discovery Early Career Researcher Award (project number DE160100900).

Conflicts of Interest: The authors declare no conflict of interest.

\section{References}

1. Bruneau, M.; Bennici, S.; Brendle, J.; Dutournie, P.; Limousy, L.; Pluchon, S. Systems for stimuli-controlled release: Materials and applications. J. Control. Release 2019, 294, 355-371. [CrossRef] [PubMed]

2. Weiser, J.R.; Saltzman, W.M. Controlled release for local delivery of drugs: Barriers and models. J. Control. Release 2014, 190, 664-673. [CrossRef] [PubMed]

3. Kim, H.; Lee, J.H.; Kim, J.E.; Kim, Y.S.; Ryu, C.H.; Lee, H.J.; Kim, H.M.; Jeon, H.; Won, H.-J.; Lee, J.-Y.; et al. Micro-/nano-sized delivery systems of ginsenosides for improved systemic bioavailability. J. Ginseng Res. 2018, 42, 361-369. [CrossRef] [PubMed]

4. Waghule, T.; Singhvi, G.; Dubey, S.K.; Pandey, M.M.; Gupta, G.; Singh, M.; Dua, K. Microneedles: A smart approach and increasing potential for transdermal drug delivery system. Biomed. Pharmacother. 2019, 109, 1249-1258. [CrossRef] [PubMed]

5. Rai, V.K.; Mishra, N.; Yadav, K.S.; Yadav, N.P. Nanoemulsion as pharmaceutical carrier for dermal and transdermal drug delivery: Formulation development, stability issues, basic considerations and applications. J. Control. Release 2018, 270, 203-225. [CrossRef] [PubMed]

6. Kathe, K.; Kathpalia, H. Film forming systems for topical and transdermal drug delivery. Asian J. Pharm. Sci. 2017, 12, 487-497. [CrossRef]

7. Kim, H.; Kim, J.T.; Barua, S.; Yoo, S.-Y.; Hong, S.-C.; Lee, K.B.; Lee, J. Seeking better topical delivery technologies of moisturizing agents for enhanced skin moisturization. Expert Opin. Drug Deliv. 2018, 15, 17-31. [CrossRef] [PubMed]

8. $\quad$ Barua, S.; Lee, D.I.; Kim, H.; Jo, K.; Yeo, S.; Yoo, S.-Y.; Jeon, H.; Lee, J.-Y.; Lee, J. Solid Lipid Nanoparticles of Serine Designed by Evaluating Affinity of Solid Lipids to Stratum Corneum for Enhanced Skin Hydration in Combination with Reed Root Extract. Bull. Korean Chem. Soc. 2018, 39, 220-226. [CrossRef]

9. Padula, C.; Colombo, G.; Nicoli, S.; Catellani, P.L.; Massimo, G.; Santi, P. Bioadhesive film for the transdermal delivery of lidocaine: In vitro and in vivo behavior. J. Control. Release 2003, 88, 277-285. [CrossRef]

10. Padula, C.; Nicoli, S.; Pescina, S.; Santi, P. Thin polymeric films for the topical delivery of propranolol. Colloids Surf. B Biointerfaces 2019, 174, 582-586. [CrossRef] [PubMed] 
11. Engelke, L.; Winter, G.; Engert, J. Application of water-soluble polyvinyl alcohol-based film patches on laser microporated skin facilitates intradermal macromolecule and nanoparticle delivery. Eur. J. Pharm. Biopharm. 2018, 128, 119-130. [CrossRef] [PubMed]

12. Carter, P.; Narasimhan, B.; Wang, Q. Biocompatible nanoparticles and vesicular systems in transdermal drug delivery for various skin diseases. Int. J. Pharm. 2019, 555, 49-62. [CrossRef] [PubMed]

13. Santos, L.F.; Correia, I.J.; Silva, A.S.; Mano, J.F. Biomaterials for drug delivery patches. Eur. J. Pharm. Sci. 2018, 118, 49-66. [CrossRef] [PubMed]

14. Kim, H.S.; Sun, X.; Lee, J.-H.; Kim, H.-W.; Fu, X.; Leong, K.W. Advanced drug delivery systems and artificial skin grafts for skin wound healing. Adv. Drug Deliv. Rev. 2018. [CrossRef] [PubMed]

15. Mendes, I.T.; Ruela, A.L.M.; Carvalho, F.C.; Freitas, J.T.J.; Bonfilio, R.; Pereira, G.R. Development and characterization of nanostructured lipid carrier-based gels for the transdermal delivery of donepezil. Colloids Surf. B Biointerfaces 2019, 177, 274-281. [CrossRef]

16. Rostamkalaei, S.S.; Akbari, J.; Saeedi, M.; Morteza-Semnani, K.; Nokhodchi, A. Topical gel of Metformin solid lipid nanoparticles: A hopeful promise as a dermal delivery system. Colloids Surf. B Biointerfaces 2019, 175, 150-157. [CrossRef] [PubMed]

17. Zhang, J.; Michniak-Kohn, B.B. Investigation of microemulsion and microemulsion gel formulations for dermal delivery of clotrimazole. Int. J. Pharm. 2018, 536, 345-352. [CrossRef]

18. Ahmed, T.A.; El-Say, K.M. Transdermal film-loaded finasteride microplates to enhance drug skin permeation: Two-step optimization study. Eur. J. Pharm. Sci. 2016, 88, 246-256. [CrossRef]

19. Contardi, M.; Heredia-Guerrero, J.A.; Perotto, G.; Valentini, P.; Pompa, P.P.; Spanò, R.; Goldoni, L.; Bertorelli, R.; Athanassiou, A.; Bayer, I.S. Transparent ciprofloxacin-povidone antibiotic films and nanofiber mats as potential skin and wound care dressings. Eur. J. Pharm. Sci. 2017, 104, 133-144. [CrossRef]

20. Aranaz, I.; Harris, R.; Navarro-García, F.; Heras, A.; Acosta, N. Chitosan based films as supports for dual antimicrobial release. Carbohydr. Polym. 2016, 146, 402-410. [CrossRef]

21. Patel, S.; Srivastava, S.; Singh, M.R.; Singh, D. Preparation and optimization of chitosan-gelatin films for sustained delivery of lupeol for wound healing. Int. J. Biol. Macromol. 2018, 107, 1888-1897. [CrossRef] [PubMed]

22. Hsu, Y.-Y.; Liu, K.-L.; Yeh, H.-H.; Lin, H.-R.; Wu, H.-L.; Tsai, J.-C. Sustained release of recombinant thrombomodulin from cross-linked gelatin/hyaluronic acid hydrogels potentiate wound healing in diabetic mice. Eur. J. Pharm. Biopharm. 2019, 135, 61-71. [CrossRef] [PubMed]

23. Ehterami, A.; Salehi, M.; Farzamfar, S.; Samadian, H.; Vaez, A.; Ghorbani, S.; Ai, J.; Sahrapeyma, H. Chitosan/alginate hydrogels containing Alpha-tocopherol for wound healing in rat model. J. Drug Deliv. Sci. Technol. 2019, 51, 204-213. [CrossRef]

24. Frederiksen, K.; Guy, R.H.; Petersson, K. The potential of polymeric film-forming systems as sustained delivery platforms for topical drugs. Expert Opin. Drug Deliv. 2016, 13, 349-360. [CrossRef] [PubMed]

25. Schuren, J.; Becker, A.; Gary Sibbald, R. A liquid film-forming acrylate for peri-wound protection: A systematic review and meta-analysis (3M $\mathrm{M}^{\mathrm{TM}}$ Cavilon ${ }^{\mathrm{TM}}$ no-sting barrier film). Int. Wound J. 2005, 2, 230-238. [CrossRef]

26. Altmann, K.; Schulze, R.D.; Friedrich, J. Polymer deposition morphology by electrospray deposition—Modifications through distance variation. Thin Solid Film. 2014, 564, 269-276. [CrossRef]

27. Tran, P.H.L.; Choe, J.S.; Tran, T.T.D.; Park, Y.M.; Lee, B.J. Design and mechanism of on-off pulsed drug release using nonenteric polymeric systems via pH modulation. AAPS PharmSciTech 2011, 12, 46-55. [CrossRef] [PubMed]

28. Maniglia, B.C.; Tessaro, L.; Ramos, A.P.; Tapia-Blácido, D.R. Which plasticizer is suitable for films based on babassu starch isolated by different methods? Food Hydrocoll. 2019, 89, 143-152. [CrossRef]

29. Suderman, N.; Isa, M.I.N.; Sarbon, N.M. The effect of plasticizers on the functional properties of biodegradable gelatin-based film: A review. Food Biosci. 2018, 24, 111-119. [CrossRef]

30. Misra, A.; Raghuvanshi, R.S.; Ganga, S.; Diwan, M.; Talwar, G.P.; Singh, O. Formulation of a transdermal system for biphasic delivery of testosterone. J. Control. Release 1996, 39, 1-7. [CrossRef]

31. Misra, A.; Pal, R.; Majumdar, S.S.; Talwar, G.P.; Singh, O. Biphasic Testosterone Delivery Profile Observed with Two Different Transdermal Formulations. Pharm. Res. 1997, 14, 1264-1268. [CrossRef] [PubMed]

32. Zurdo Schroeder, I.; Franke, P.; Schaefer, U.F.; Lehr, C.-M. Development and characterization of film forming polymeric solutions for skin drug delivery. Eur. J. Pharm. Biopharm. 2007, 65, 111-121. [CrossRef] [PubMed] 
33. Schroeder, I.Z.; Franke, P.; Schaefer, U.F.; Lehr, C.-M. Delivery of ethinylestradiol from film forming polymeric solutions across human epidermis in vitro and in vivo in pigs. J. Control. Release 2007, 118, 196-203. [CrossRef]

34. Gohel, M.C.; Nagori, S.A. Fabrication of Modified Transport Fluconazole Transdermal Spray Containing Ethyl Cellulose and Eudragit ${ }^{\circledR}$ RS100 as Film Formers. AAPS PharmSciTech 2009, 10, 684-691. [CrossRef] [PubMed]

35. Mori, N.M.; Patel, P.; Sheth, N.R.; Rathod, L.V.; Ashara, K.C. Fabrication and characterization of film-forming voriconazole transdermal spray for the treatment of fungal infection. Bull. Fac. Pharm. Cairo Univ. 2017, 55, 41-51. [CrossRef]

36. Acrux History. Available online: http://www.acrux.com.au/about/history/ (accessed on 25 March 2019).

37. Wang, C.; Ilani, N.; Arver, S.; McLachlan, R.I.; Soulis, T.; Watkinson, A. Efficacy and safety of the $2 \%$ formulation of testosterone topical solution applied to the axillae in androgen-deficient men. Clin. Endocrinol. 2011, 75, 836-843. [CrossRef] [PubMed]

38. Axiron ${ }^{\circledR}$ (Testosterone) Pump Applicator, Axiron ${ }^{\circledR}$ (Testosterone) Twist Applicator. Available online: https://www.lilly.com/products/historic-products (accessed on 25 March 2019).

39. Lamisil Once ${ }^{\circledR} 4 \mathrm{~g}$. Single Dose Treatment For Athlete's Foot. Available online: http://lamisil.com.au/productoncefilm.html (accessed on 25 March 2019).

40. Kienzler, J.L.; Queille-Roussel, C.; Mugglestone, C.; Ortonne, J.P.; Larnier, C. Stratum corneum pharmaco-kinetics of the anti-fungal drug, terbinafine, in a novel topical formulation, for single-dose application in dermatophytoses. Curr. Med. Res. Opin. 2007, 23, 1293-1302. [CrossRef]

41. MedSpray ${ }^{\circledR}$. Available online: https://www.medpharm.com/en/medspray/ (accessed on 25 March 2019).

42. Jones, S.A.; Reid, M.L.; Brown, M.B. Determining Degree of Saturation after Application of Transiently Supersaturated Metered Dose Aerosols for Topical Delivery of Corticosteroids. J. Pharm. Sci. 2009, 98, 543-554. [CrossRef]

43. Platform Technology. Available online: https://epinamics.com/the-liqui-patch (accessed on 25 March 2019).

44. Kim, D.W.; Kim, K.S.; Seo, Y.G.; Lee, B.-J.; Park, Y.J.; Youn, Y.S.; Kim, J.O.; Yong, C.S.; Jin, S.G.; Choi, H.-G. Novel sodium fusidate-loaded film-forming hydrogel with easy application and excellent wound healing. Int. J. Pharm. 2015, 495, 67-74. [CrossRef]

45. Bryan, H.A.; Alster, T.S. The S-Caine Peel: A Novel Topical Anesthetic for Cutaneous Laser Surgery. Dermatol. Surg. 2002, 28, 999-1003. [CrossRef]

46. Chen, J.Z.S.; Alexiades-Armenakas, M.R.; Bernstein, L.J.; Jacobson, L.G.; Friedman, P.M.; Geronemus, R.G. Two Randomized, Double-Blind, Placebo-Controlled Studies Evaluating the S-Caine Peel for Induction of Local Anesthesia Before Long-Pulsed Nd:YAG Laser Therapy for Leg Veins. Dermatol. Surg. 2003, 29, 1012-1018. [CrossRef]

47. Doshi, S.N.; Friedman, P.M.; Marquez, D.K.; Goldberg, L.H. Thirty-Minute Application of the S-Caine Peel Prior to Nonablative Laser Treatment. Dermatol. Surg. 2003, 29, 1008-1011. [CrossRef] [PubMed]

48. Chen, J.Z.S.; Jacobson, L.G.; Bakus, A.D.; Garden, J.M.; Yaghmai, D.; Bernstein, L.J.; Geronemus, R.G. Evaluation of the S-Caine Peel for Induction of Local Anesthesia for Laser-Assisted Tattoo Removal: Randomized, Double-Blind, Placebo-Controlled, Multicenter Study. Dermatol. Surg. 2006, 31, 281-286. [CrossRef]

49. Alster, T. Review of Lidocaine/Tetracaine Cream as a Topical Anesthetic for Dermatologic Laser Procedures. Pain Ther. 2013, 2, 11-19. [CrossRef] [PubMed]

50. An, N.M.; Kim, D.D.; Lee, C.H.; Shin, Y.H. Development of a novel soft hydrogel for the transdermal delivery of testosterone. Drug Dev. Ind. Pharm. 2003, 29, 99-105. [CrossRef]

51. Guo, J.-H. Investigating the Surface Properties and Bioadhesion of Buccal Patches. J. Pharm. Pharmacol. 1994, 46, 647-650. [CrossRef] [PubMed]

52. Guo, R.; Du, X.; Zhang, R.; Deng, L.; Dong, A.; Zhang, J. Bioadhesive film formed from a novel organic-inorganic hybrid gel for transdermal drug delivery system. Eur. J. Pharm. Biopharm. 2011, 79, 574-583. [CrossRef]

53. Gupta, A.; Kowalczuk, M.; Heaselgrave, W.; Britland, S.T.; Martin, C.; Radecka, I. The production and application of hydrogels for wound management: A review. Eur. Polym. J. 2019, 111, 134-151. [CrossRef]

54. Yang, S.; Yang, Y.; Cui, S.; Feng, Z.; Du, Y.; Song, Z.; Tong, Y.; Yang, L.; Wang, Z.; Zeng, H.; et al. Chitosan-polyvinyl alcohol nanoscale liquid film-forming system facilitates MRSA-infected wound healing by enhancing antibacterial and antibiofilm properties. Int. J. Nanomed. 2018, 13, 4987-5002. [CrossRef] 
55. DuraPeel. Available online: http://www.crescitatherapeutics.com/technology/durapeel/ (accessed on 25 March 2019).

56. Lunter, D.J.; Daniels, R. New film forming emulsions containing Eudragit ${ }^{\circledR}$ NE and/or RS 30D for sustained dermal delivery of nonivamide. Eur. J. Pharm. Biopharm. 2012, 82, 291-298. [CrossRef]

57. Lunter, D.; Daniels, R. In vitro Skin Permeation and Penetration of Nonivamide from Novel Film-Forming Emulsions. Skin Pharmacol. Physiol. 2013, 26, 139-146. [CrossRef] [PubMed]

58. Heck, R.; Hermann, S.; Lunter, D.J.; Daniels, R. Film-forming formulations containing porous silica for the sustained delivery of actives to the skin. Eur. J. Pharm. Biopharm. 2016, 108, 1-8. [CrossRef] [PubMed]

59. Frederiksen, K.; Guy, R.H.; Petersson, K. Formulation considerations in the design of topical, polymeric film-forming systems for sustained drug delivery to the skin. Eur. J. Pharm. Biopharm. 2015, 91, 9-15. [CrossRef] [PubMed]

60. Potts, R.O.; Guy, R.H. Predicting Skin Permeability. Pharm. Res. 1992, 9, 663-669. [CrossRef] [PubMed]

61. Ito, Y.; Yoshimura, M.; Tanaka, T.; Takada, K. Effect of Lipophilicity on the Bioavailability of Drugs After Percutaneous Administration by Dissolving Microneedles. J. Pharm. Sci. 2012, 101, 1145-1156. [CrossRef]

62. Padula, C.; Nicoli, S.; Colombo, P.; Santi, P. Single-layer transdermal film containing lidocaine: Modulation of drug release. Eur. J. Pharm. Biopharm. 2007, 66, 422-428. [CrossRef]

63. Benita, S.; Dor, P.; Aronhime, M.; Marom, G. Permeability and mechanical properties of a new polymer: Cellulose hydrogen phthalate. Int. J. Pharm. 1986, 33, 71-80. [CrossRef]

64. Lecomte, F.; Siepmann, J.; Walther, M.; MacRae, R.J.; Bodmeier, R. Polymer blends used for the aqueous coating of solid dosage forms: Importance of the type of plasticizer. J. Control. Release 2004, 99, 1-13. [CrossRef]

65. Iervolino, M.; Cappello, B.; Raghavan, S.L.; Hadgraft, J. Penetration enhancement of ibuprofen from supersaturated solutions through human skin. Int. J. Pharm. 2001, 212, 131-141. [CrossRef]

66. Williams, A.C.; Barry, B.W. Penetration enhancers. Adv. Drug Deliv. Rev. 2012, 64, 128-137. [CrossRef]

67. Davis, A.F.; Hadgraft, J. Effect of supersaturation on membrane transport: 1. Hydrocortisone acetate. Int. J. Pharm. 1991, 76, 1-8. [CrossRef]

68. Moser, K.; Kriwet, K.; Froehlich, C.; Kalia, Y.N.; Guy, R.H. Supersaturation: Enhancement of Skin Penetration and Permeation of a Lipophilic Drug. Pharm. Res. 2001, 18, 1006-1011. [CrossRef] [PubMed]

69. Edwards, A.; Qi, S.; Liu, F.; Brown, M.B.; McAuley, W.J. Rationalising polymer selection for supersaturated film forming systems produced by an aerosol spray for the transdermal delivery of methylphenidate. Eur. J. Pharm. Biopharm. 2017, 114, 164-174. [CrossRef] [PubMed]

70. Qi, S.; Belton, P.; Nollenberger, K.; Clayden, N.; Reading, M.; Craig, D.Q.M. Characterisation and Prediction of Phase Separation in Hot-Melt Extruded Solid Dispersions: A Thermal, Microscopic and NMR Relaxometry Study. Pharm. Res. 2010, 27, 1869-1883. [CrossRef] [PubMed]

71. Heck, R.; Lukić, M.Ž.; Savić, S.D.; Daniels, R.; Lunter, D.J. Ex vivo skin permeation and penetration of nonivamide from and in vivo skin tolerability of film-forming formulations containing porous silica. Eur. J. Pharm. Sci. 2017, 106, 34-40. [CrossRef] [PubMed]

72. Oh, D.-W.; Kang, J.-H.; Lee, H.-J.; Han, S.-D.; Kang, M.-H.; Kwon, Y.-H.; Jun, J.-H.; Kim, D.-W.; Rhee, Y.-S.; Kim, J.-Y.; et al. Formulation and in vitro/in vivo evaluation of chitosan-based film forming gel containing ketoprofen. Drug Deliv. 2017, 24, 1056-1066. [CrossRef]

73. Garvie-Cook, H.; Frederiksen, K.; Petersson, K.; Guy, R.H.; Gordeev, S.N. Biophysical elucidation of the mechanism of enhanced drug release and topical delivery from polymeric film-forming systems. J. Control. Release 2015, 212, 103-112. [CrossRef] [PubMed]

74. Trey, S.M.; Wicks, D.A.; Mididoddi, P.K.; Repka, M.A. Delivery of itraconazole from extruded HPC films. Drug Dev. Ind. Pharm. 2007, 33, 727-735. [CrossRef]

75. Marucci, M.; Andersson, H.; Hjärtstam, J.; Stevenson, G.; Baderstedt, J.; Stading, M.; Larsson, A.; von Corswant, C. New insights on how to adjust the release profile from coated pellets by varying the molecular weight of ethyl cellulose in the coating film. Int. J. Pharm. 2013, 458, 218-223. [CrossRef]

76. Thao, T.D.T.; Phuong, H.L.T. Perspectives on Strategies Using Swellable Polymers in Solid Dispersions for Controlled Drug Release. Curr. Pharm. Des. 2017, 23, 1639-1648. [CrossRef]

77. Phaechamud, T;; Mahadlek, J. Solvent exchange-induced in situ forming gel comprising ethyl cellulose-antimicrobial drugs. Int. J. Pharm. 2015, 494, 381-392. [CrossRef] [PubMed] 
78. Patel, D.P.; Setty, C.M.; Mistry, G.N.; Patel, S.L.; Patel, T.J.; Mistry, P.C.; Rana, A.K.; Patel, P.K.; Mishra, R.S. Development and Evaluation of Ethyl Cellulose-Based Transdermal Films of Furosemide for Improved In Vitro Skin Permeation. AAPS PharmSciTech 2009, 10, 437-442. [CrossRef]

79. Shin, T.H.; Ho, M.J.; Kim, S.R.; Im, S.H.; Kim, C.H.; Lee, S.; Kang, M.J.; Choi, Y.W. Formulation and in vivo pharmacokinetic evaluation of ethyl cellulose-coated sustained release multiple-unit system of tacrolimus. Int. J. Biol. Macromol. 2018, 109, 544-550. [CrossRef] [PubMed]

80. Siepmann, F.; Siepmann, J.; Walther, M.; MacRae, R.J.; Bodmeier, R. Polymer blends for controlled release coatings. J. Control. Release 2008, 125, 1-15. [CrossRef] [PubMed]

81. Rowe, R.C. The effect of the molecular weight of ethyl cellulose on the drug release properties of mixed films of ethyl cellulose and hydroxypropylmethylcellulose. Int. J. Pharm. 1986, 29, 37-41. [CrossRef]

82. Larsson, M.; Hjärtstam, J.; Berndtsson, J.; Stading, M.; Larsson, A. Effect of ethanol on the water permeability of controlled release films composed of ethyl cellulose and hydroxypropyl cellulose. Eur. J. Pharm. Biopharm. 2010, 76, 428-432. [CrossRef] [PubMed]

83. Marucci, M.; Hjärtstam, J.; Ragnarsson, G.; Iselau, F.; Axelsson, A. Coated formulations: New insights into the release mechanism and changes in the film properties with a novel release cell. J. Control. Release 2009, 136, 206-212. [CrossRef]

84. Marucci, M.; Ragnarsson, G.; von Corswant, C.; Welinder, A.; Jarke, A.; Iselau, F.; Axelsson, A. Polymer leaching from film coating: Effects on the coating transport properties. Int. J. Pharm. 2011, 411, 43-48. [CrossRef]

85. Andersson, H.; Hjärtstam, J.; Stading, M.; von Corswant, C.; Larsson, A. Effects of molecular weight on permeability and microstructure of mixed ethyl-hydroxypropyl-cellulose films. Eur. J. Pharm. Sci. 2013, 48, 240-248. [CrossRef]

86. Thombre, A.G.; DeNoto, A.R.; Falkner, F.C.; Lazar, J.D. In vitro/in vivo correlations of sustained-release coated multiparticulate formulations of doxazosin. Int. J. Pharm. 1994, 111, 181-189. [CrossRef]

87. Li, X.; Zhang, R.; Liang, R.; Liu, W.; Wang, C.; Su, Z.; Sun, F.; Li, Y. Preparation and characterization of sustained-release rotigotine film-forming gel. Int. J. Pharm. 2014, 460, 273-279. [CrossRef] [PubMed]

88. Phuong, H.L.T.; Wei, D.; Beom-Jin, L.; Thao, T.D.T. Current Designs of Polymer Blends in Solid Dispersions for Improving Drug Bioavailability. Curr. Drug Metab. 2018, 19, 1111-1118. [CrossRef]

89. Borges, A.F.; Silva, C.; Coelho, J.F.J.; Simões, S. Oral films: Current status and future perspectives: I-Galenical development and quality attributes. J. Control. Release 2015, 206, 1-19. [CrossRef] [PubMed]

90. Alanazi, F.K.; Abdel Rahman, A.A.; Mahrous, G.M.; Alsarra, I.A. Formulation and physicochemical characterisation of buccoadhesive films containing ketorolac. J. Drug Deliv. Sci. Technol. 2007, 17, 183-192. [CrossRef]

91. El-Setouhy, D.A.; El-Malak, N.S.A. Formulation of a Novel Tianeptine Sodium Orodispersible Film. AAPS PharmSciTech 2010, 11, 1018-1025. [CrossRef]

92. Tran, T.T.D.; Tran, P.H.L.; Choi, H.G.; Han, H.K.; Lee, B.J. The roles of acidifiers in solid dispersions and physical mixtures. Int. J. Pharm. 2010, 384, 60-66. [CrossRef] [PubMed]

93. Poonguzhali, R.; Basha, S.K.; Kumari, V.S. Synthesis and characterization of chitosan-PVP-nanocellulose composites for in-vitro wound dressing application. Int. J. Biol. Macromol. 2017, 105, 111-120. [CrossRef]

94. Rosa, R.M.; Silva, J.C.; Sanches, I.S.; Henriques, C. Simultaneous photo-induced cross-linking and silver nanoparticle formation in a PVP electrospun wound dressing. Mater. Lett. 2017, 207, 145-148. [CrossRef]

95. Rasool, A.; Ata, S.; Islam, A. Stimuli responsive biopolymer (chitosan) based blend hydrogels for wound healing application. Carbohydr. Polym. 2019, 203, 423-429. [CrossRef]

96. Archana, D.; Singh, B.K.; Dutta, J.; Dutta, P.K. In vivo evaluation of chitosan-PVP-titanium dioxide nanocomposite as wound dressing material. Carbohydr. Polym. 2013, 95, 530-539. [CrossRef]

97. Wang, M.; Xu, L.; Hu, H.; Zhai, M.; Peng, J.; Nho, Y.; Li, J.; Wei, G. Radiation synthesis of PVP/CMC hydrogels as wound dressing. Nucl. Instrum. Methods Phys. Res. Sect. B Beam Interact. Mater. At. 2007, 265, 385-389. [CrossRef]

98. Ammar, H.O.; Ghorab, M.; Mahmoud, A.A.; Makram, T.S.; Ghoneim, A.M. Rapid pain relief using transdermal film forming polymeric solution of ketorolac. Pharm. Dev. Technol. 2013, 18, 1005-1016. [CrossRef] [PubMed]

99. Liu, H.; Taylor, L.S.; Edgar, K.J. The role of polymers in oral bioavailability enhancement; a review. Polymer 2015, 77, 399-415. [CrossRef] 
100. Teodorescu, M.; Bercea, M.; Morariu, S. Biomaterials of PVA and PVP in medical and pharmaceutical applications: Perspectives and challenges. Biotechnol. Adv. 2019, 37, 109-131. [CrossRef] [PubMed]

101. Hameed, N.; Glattauer, V.; Ramshaw, J.A.M. Evaluation of polyvinyl alcohol composite membranes containing collagen and bone particles. J. Mech. Behav. Biomed. Mater. 2015, 48, 38-45. [CrossRef] [PubMed]

102. Kamoun, E.A.; Chen, X.; Mohy Eldin, M.S.; Kenawy, E.-R.S. Crosslinked poly(vinyl alcohol) hydrogels for wound dressing applications: A review of remarkably blended polymers. Arab. J. Chem. 2015, 8, 1-14. [CrossRef]

103. Jeong Kim, S.; Jun Park, S.; Young Kim, I.; Hee Lee, Y.; Kim, S.I. Thermal characteristics of poly(vinyl alcohol) and poly(vinylpyrrolidone) IPNs. J. Appl. Polym. Sci. 2002, 86, 1844-1847. [CrossRef]

104. Morariu, S.; Bercea, M.; Teodorescu, M.; Avadanei, M. Tailoring the properties of poly(vinyl alcohol)/poly(vinylpyrrolidone) hydrogels for biomedical applications. Eur. Polym. J. 2016, 84, 313-325. [CrossRef]

105. Thomas, J.; Gomes, K.; Lowman, A.; Marcolongo, M. The effect of dehydration history on PVA/PVP hydrogels for nucleus pulposus replacement. J. Biomed. Mater. Res. Part B Appl. Biomater. 2004, 69B, 135-140. [CrossRef]

106. Abou-Aiad, T.H.M.; Abd-El-Nour, K.N.; Hakim, I.K.; Elsabee, M.Z. Dielectric and interaction behavior of chitosan/polyvinyl alcohol and chitosan/polyvinyl pyrrolidone blends with some antimicrobial activities. Polymer 2006, 47, 379-389. [CrossRef]

107. Liu, L.; Gao, Q.; Lu, X.; Zhou, H. In situ forming hydrogels based on chitosan for drug delivery and tissue regeneration. Asian J. Pharm. Sci. 2016, 11, 673-683. [CrossRef]

108. Ahsan, S.M.; Thomas, M.; Reddy, K.K.; Sooraparaju, S.G.; Asthana, A.; Bhatnagar, I. Chitosan as biomaterial in drug delivery and tissue engineering. Int. J. Biol. Macromol. 2018, 110, 97-109. [CrossRef] [PubMed]

109. Archana, D.; Singh, B.K.; Dutta, J.; Dutta, P.K. Chitosan-PVP-nano silver oxide wound dressing: In vitro and in vivo evaluation. Int. J. Biol. Macromol. 2015, 73, 49-57. [CrossRef] [PubMed]

110. Laffleur, F. Mucoadhesive polymers for buccal drug delivery. Drug Dev. Ind. Pharm. 2014, 40, 591-598. [CrossRef] [PubMed]

111. Morales, J.O.; McConville, J.T. Manufacture and characterization of mucoadhesive buccal films. Eur. J. Pharm. Biopharm. 2011, 77, 187-199. [CrossRef] [PubMed]

112. Furuike, T.; Komoto, D.; Hashimoto, H.; Tamura, H. Preparation of chitosan hydrogel and its solubility in organic acids. Int. J. Biol. Macromol. 2017, 104, 1620-1625. [CrossRef]

113. Monti, D.; Tampucci, S.; Chetoni, P.; Burgalassi, S.; Mailland, F. Ciclopirox vs. Amorolfine: In Vitro Penetration Into and Permeation Through Human Healthy Nails of Commercial Nail Lacquers. J. Drugs Dermatol. 2014, 13, 143-147.

114. Qin, C.; Li, H.; Xiao, Q.; Liu, Y.; Zhu, J.; Du, Y. Water-solubility of chitosan and its antimicrobial activity. Carbohydr. Polym. 2006, 63, 367-374. [CrossRef]

115. Kumar, M.N.V.R.; Muzzarelli, R.A.A.; Muzzarelli, C.; Sashiwa, H.; Domb, A.J. Chitosan Chemistry and Pharmaceutical Perspectives. Chem. Rev. 2004, 104, 6017-6084. [CrossRef]

116. Cilurzo, F.; Selmin, F.; Gennari, C.G.M.; Montanari, L.; Minghetti, P. Application of methyl methacrylate copolymers to the development of transdermal or loco-regional drug delivery systems. Expert Opin. Drug Deliv. 2014, 11, 1033-1045. [CrossRef]

117. Garvie-Cook, H.; Frederiksen, K.; Petersson, K.; Guy, R.H.; Gordeev, S. Characterization of Topical Film-Forming Systems Using Atomic Force Microscopy and Raman Microspectroscopy. Mol. Pharm. 2015, 12, 751-757. [CrossRef] [PubMed]

118. Nollenberger, K.; Albers, J. Poly(meth)acrylate-based coatings. Int. J. Pharm. 2013, 457, 461-469. [CrossRef] [PubMed]

119. Kucera, S.; Shah, N.H.; Malick, A.W.; Infeld, M.H.; McGinity, J.W. Influence of an Acrylic Polymer Blend on the Physical Stability of Film-Coated Theophylline Pellets. AAPS PharmSciTech 2009, 10, 864. [CrossRef] [PubMed]

120. Wagner, K.G.; Maus, M.; Kornherr, A.; Zifferer, G. Glass transition temperature of a cationic polymethacrylate dependent on the plasticizer content-Simulation vs. experiment. Chem. Phys. Lett. 2005, 406, 90-94. [CrossRef]

121. Ammar, H.O.; Ghorab, M.; El-Nahhas, S.A.; Kamel, R. Polymeric Matrix System for Prolonged Delivery of Tramadol Hydrochloride, Part I: Physicochemical Evaluation. AAPS PharmSciTech 2009, 10, 7-20. [CrossRef] 
122. Mahnaj, T.; Ahmed, S.U.; Plakogiannis, F.M. Evaluating the efficacy of a group of nontraditional plasticizers on the glass transition temperature of ethyl cellulose polymer. Drug Dev. Ind. Pharm. 2011, 37, 342-350. [CrossRef]

123. Gennari, C.G.M.; Selmin, F.; Franzè, S.; Musazzi, U.M.; Quaroni, G.M.G.; Casiraghi, A.; Cilurzo, F. A glimpse in critical attributes to design cutaneous film forming systems based on ammonium methacrylate. J. Drug Deliv. Sci. Technol. 2017, 41,157-163. [CrossRef]

124. Kandile, N.G.; Mohamed, H.M. Chitosan nanoparticle hydrogel based sebacoyl moiety with remarkable capability for metal ion removal from aqueous systems. Int. J. Biol. Macromol. 2019, 122, 578-586. [CrossRef]

125. Ashrafi, H.; Azadi, A. Chitosan-based hydrogel nanoparticle amazing behaviors during transmission electron microscopy. Int. J. Biol. Macromol. 2016, 84, 31-34. [CrossRef]

126. Hamidi, M.; Azadi, A.; Rafiei, P. Hydrogel nanoparticles in drug delivery. Adv. Drug Deliv. Rev. 2008, 60, 1638-1649. [CrossRef]

127. Kamar, S.S.; Abdel-Kader, D.H.; Rashed, L.A. Beneficial effect of Curcumin Nanoparticles-Hydrogel on excisional skin wound healing in type-I diabetic rat: Histological and immunohistochemical studies. Ann. Anat. Anat. Anz. 2019, 222, 94-102. [CrossRef] [PubMed]

128. Grillo, R.; Dias, F.V.; Querobino, S.M.; Alberto-Silva, C.; Fraceto, L.F.; de Paula, E.; de Araujo, D.R. Influence of hybrid polymeric nanoparticle/thermosensitive hydrogels systems on formulation tracking and in vitro artificial membrane permeation: A promising system for skin drug-delivery. Colloids Surf. B Biointerfaces 2019, 174, 56-62. [CrossRef] [PubMed]

129. Choipang, C.; Chuysinuan, P.; Suwantong, O.; Ekabutr, P.; Supaphol, P. Hydrogel wound dressings loaded with PLGA/ciprofloxacin hydrochloride nanoparticles for use on pressure ulcers. J. Drug Deliv. Sci. Technol. 2018, 47, 106-114. [CrossRef]

130. Ilgin, P.; Ozay, O.; Ozay, H. A novel hydrogel containing thioether group as selective support material for preparation of gold nanoparticles: Synthesis and catalytic applications. Appl. Catal. B Environ. 2019, 241, 415-423. [CrossRef]

131. Dos Santos, T.C.; Hernández, R.; Rescignano, N.; Boff, L.; Reginatto, F.H.; Simões, C.M.O.; de Campos, A.M.; Mijangos, C. Nanocomposite chitosan hydrogels based on PLGA nanoparticles as potential biomedical materials. Eur. Polym. J. 2018, 99, 456-463. [CrossRef]

132. De Matos Fonseca, J.; de Fátima Medeiros, S.; Alves, G.M.; dos Santos, D.M.; Campana-Filho, S.P.; dos Santos, A.M. Chitosan microparticles embedded with multi-responsive poly(N-vinylcaprolactam-co-itaconic acid-co-ethylene-glycol dimethacrylate)-based hydrogel nanoparticles as a new carrier for delivery of hydrophobic drugs. Colloids Surf. B Biointerfaces 2019, 175, 73-83. [CrossRef]

133. Tuong, N.G.N.; Van-Thanh, T.; Wei, D.; Phuong, H.L.T.; Thao, T.D.T. Nanoprecipitation for Poorly Water-Soluble Drugs. Curr. Drug Metab. 2017, 18, 1000-1015. [CrossRef]

134. Nguyen, K.T.; Pham, M.N.; Vo, T.V.; Duan, W.; Tran, P.H.; Tran, T.T. Strategies of Engineering Nanoparticles for Treating Neurodegenerative Disorders. Curr. Drug Metab. 2017, 18, 1-12. [CrossRef] [PubMed]

135. Dinh, H.T.T.; Tran, P.H.L.; Duan, W.; Lee, B.-J.; Tran, T.T.D. Nano-sized solid dispersions based on hydrophobic-hydrophilic conjugates for dissolution enhancement of poorly water-soluble drugs. Int. J. Pharm. 2017, 533, 93-98. [CrossRef]

136. Tran, T.T.D.; Tran, P.H.L.; Nguyen, K.T.; Tran, V.T. Nano-precipitation: Preparation and application in the field of pharmacy. Curr. Pharm. Des. 2016, 22, 2997-3006. [CrossRef]

137. Hurler, J.; Škalko-Basnet, N. Potentials of Chitosan-Based Delivery Systems in Wound Therapy: Bioadhesion Study. J. Funct. Biomater. 2012, 3, 37-48. [CrossRef] [PubMed]

138. Asasutjarit, R.; Larpmahawong, P.; Fuongfuchat, A.; Sareedenchai, V.; Veeranondha, S. Physicochemical properties and anti-propionibacterium acnes activity of film-forming solutions containing alpha-mangostin-rich extract. AAPS PharmSciTech 2014, 15, 306-316. [CrossRef]

139. Veikauskait, I.; Briedis, V. Effect of Film-Forming Polymers on Release of Naftifine Hydrochloride from Nail Lacquers. Int. J. Polym. Sci. 2017, 2017, 7. [CrossRef]

140. Tran, P.H.L.; Tran, T.T.D.; Park, J.B.; Lee, B.J. Controlled release systems containing solid dispersions: Strategies and mechanisms. Pharm. Res. 2011, 28, 2353-2378. [CrossRef] [PubMed]

141. Tran, T.T.D.; Tran, P.H.L.; Khanh, T.N.; Van, T.V.; Lee, B.J. Solubilization of poorly water-soluble drugs using solid dispersions. Recent Pat. Drug Deliv. Formul. 2013, 7, 122-133. [CrossRef] 
142. Nguyen, M.N.U.; Tran, P.H.L.; Tran, T.T.D. A single-layer film coating for colon-targeted oral delivery. Int. J. Pharm. 2019, 559, 402-409. [CrossRef] [PubMed]

143. Treffel, P.; Muret, P.; Muret-D'Aniello, P.; Coumes-Marquet, S.; Agache, P. Effect of Occlusion on in vitro Percutaneous Absorption of Two Compounds with Different Physicochemical Properties. Skin Pharmacol. Physiol. 1992, 5, 108-113. [CrossRef]

144. Qiao, G.L.; Chang, S.K.; Riviere, J.E. Effects of Anatomical Site and Occlusion on the Percutaneous Absorption and Residue Pattern of 2,6-(ring-14C)Parathion in vivo in Pigs. Toxicol. Appl. Pharmacol. 1993, 122, 131-138. [CrossRef]

145. Hotchkiss, S.A.M.; Miller, J.M.; Caldwell, J. Percutaneous absorption of benzyl acetate through rat skin in vitro. 2. Effect of vehicle and occlusion. Food Chem. Toxicol. 1992, 30, 145-153. [CrossRef]

146. Herkenne, C.; Naik, A.; Kalia, Y.N.; Hadgraft, J.; Guy, R.H. Pig Ear Skin ex Vivo as a Model for in Vivo Dermatopharmacokinetic Studies in Man. Pharm. Res. 2006, 23, 1850-1856. [CrossRef]

147. Klang, V.; Schwarz, J.C.; Lenobel, B.; Nadj, M.; Auböck, J.; Wolzt, M.; Valenta, C. In vitro vs. in vivo tape stripping: Validation of the porcine ear model and penetration assessment of novel sucrose stearate emulsions. Eur. J. Pharm. Biopharm. 2012, 80, 604-614. [CrossRef] [PubMed]

148. Czajkowska-Kośnik, A.; Szekalska, M.; Winnicka, K. Nanostructured lipid carriers: A potential use for skin drug delivery systems. Pharmacol. Rep. 2019, 71, 156-166. [CrossRef] [PubMed]

149. Wiedersberg, S.; Leopold, C.S.; Guy, R.H. Dermatopharmacokinetics of betamethasone 17-valerate: Influence of formulation viscosity and skin surface cleaning procedure. Eur. J. Pharm. Biopharm. 2009, 71, 362-366. [CrossRef] [PubMed]

150. Zhang, Q.; Song, Y.; Page, S.W.; Garg, S. Evaluation of Transdermal Drug Permeation as Modulated by Lipoderm and Pluronic Lecithin Organogel. J. Pharm. Sci. 2018, 107, 587-594. [CrossRef] [PubMed]

(C) 2019 by the authors. Licensee MDPI, Basel, Switzerland. This article is an open access article distributed under the terms and conditions of the Creative Commons Attribution (CC BY) license (http://creativecommons.org/licenses/by/4.0/). 